\title{
UPAYA MENINGKATKAN KETERAMPILAN PROSES SAINS MENGGUNAKAN MODEL INKUIRI TERBIMBING PADA MATERI GETARAN HARMONIS KELAS X MIPA 4 SMA NEGERI 4 BANJARMASIN TAHUN PELAJARAN 2017/2018
}

\author{
Solikatun Fujiastuti ${ }^{1}$
}

\section{SMA NEGERI 4 BANJARMASIN}

\begin{abstract}
ABSTRAK
Keterampilan proses sains siswa kelas X MIPA 4 SMA Negeri 4 Banjarmasin tergolong rendah. Hal ini disebabkan guru jarang mengajak siswa untuk melakukan kegiatan percobaan. Oleh sebab itu, dilakukan penelitian untuk meningkatkan keterampilan proses sains siswa kelas X MIPA 4 SMA Negeri 4 Banjarmasin. Penelitian ini merupakan penelitian tindakan kelas yang menggunakan model Kemmis dan Mc Taggart, yang terdiri dari 2 siklus, setiap siklus terdiri dari 2 kali pertemuan. Setiap siklus meliputi perencanaan, pelaksanaan/pengamatan dan refleksi. Instrumen yang digunakan adalah lembar pengamatan keterlaksanaan RPP, lembar pengamatan keterampilan proses sains, dan lembar tes hasil belajar. Data dianalisis secara deskriptif kualitatif dan kuantitatif. Temuan penelitian dari siklus I ke siklus II, yaitu (1) Keterlakasanaa RPP pada siklus I pertemuan I dan II sebesar $85,88 \%$, dan $89,51 \%$, pada siklus II pertemuan I dan II sebesar $92,74 \%$ dan $96,37 \%$. Keseluruhan berkategori sangat baik; (2) Keterampilan proses sains siklus I pertemuan I dan II sebesar $75,22 \%$ dan $84,32 \%$. Siklus II pertemuan I dan II sebesar $93,60 \%$ dan $96,80 \%$. Keterampilan proses sains siswa mengalami peningkatan; (3) Hasil belajar siswa mengalami peningkatan klasikal sebesar $21,42 \%$ dan $89,28 \%$. Berdasarkan penelitian yang dilakukan diperoleh simpulan bahwa model pembelajaran inkuiri terbimbing mampu meningkatkan keterampilan proses sains dan hasil belajar siswa kelas X MIPA 4 SMA Negeri 4 Banjarmasin.
\end{abstract}

Kata Kunci: Keterampilan Proses Sains, Inkuri Terbimbing, Hasil Belajar

\section{PENDAHULUAN}

\section{A. Latar Belakang}

Undang - Undang Nomor 20 Tahun 2003 tentang sistem pendidikan Indonesia menyatakan bahwa pendidikan adalah usaha sadar dan terencana untuk mewujudkan suasana belajar dan proses pembelajaran agar peserta didik secara aktif mengembangkan potensi dirinya untuk memiliki kekuatan spiritual keagamaan, pengendalian diri, kepribadian, akhlak mulia, serta keterampilan yang diperlukan dirinya, masyarakat, bangsa dan negara.

Kurikulum terbaru yang diterapkan di Indonesia adalah kurikulum 2013. Pembelajaran yang ingin dicapai pada kurikulum 2013, yaitu pembelajaran yang 
aktif, pembelajaran yang berpusat pada siswa di mana siswa aktif mencari pengetahuan. Pada kurikulum 2013, pembelajaran siswa aktif dapat diperkuat dengan menggunakan model pembelajaran pendekatan sains (Permendikbud Nomor 69 Tahun 2013). Berdasarkan hal tersebut pembelajaran diharapkan tidak hanya mengedepankan pembelajaran berpikir kritis saja tetapi juga menekankan menggunakan pendekatan sains. Dengan menggunakan pendekatan sains siswa diharapkan mampu meningkatkan keterampilan-keterampilan proses sains.

Berdasarkan hasil observasi yang dilakukan di kelas X MIPA 4 SMA Negeri 4 Banjarmasin, pembelajaran yang dilakukan masih berpusat pada guru sehingga siswa kurang aktif dalam pembelajaran berlangsung. Selain itu, guru juga kurang melatih keterampilan proses sains siswa, seperti merumuskan masalah, merumuskan hipotesis, mengidentifikasi variabel, melakukan percobaan, menganalisis, dan menarik kesimpulan. Rendahnya keterampilan proses sains dikelas XI MIPA 4 dengan jumlah siswa 36, dapat dilihat dari hasil LKPD yang telah diberikan kepada siswa sebagai data awal. Diperoleh persentase keterampilan proses sains secara klasikal yang sangat rendah, yaitu 27,36 \%, dengan masing-masing persentase secara klasikal setiap indikator, yaitu merumuskan masalah sebesar 34,72\%, merumuskan hipotesis 20,83\%, mengidentifikasi variabel 19,44\%, menganalisis 29,86\% dan menarik kesimpulan sebesar 31,94\%. Selain keterampilan proses sains yang rendah, nilai ulangan akhir semester (UAS) juga rendah. Berdasarkan data ketuntasan klasikal untuk kelas X MIPA 4, siswa yang tuntas hanya 55,5 \% dengan kriteria ketuntasan minimum atau KKM, yaitu sebesar 65 hasil persentase klasikal hasil belajar belum memenuhi ketuntasan klasikal yang ditentukan sekolah yaitu sebesar 70\%. Terdapat 20 orang siswa yang tuntas dari 36 siswa dan persentase siswa yang belum mencapai KKM adalah sebesar 44,5\%. Berdasarkan data tersebut dapat disimpulkan bahwa keterampilan proses sains dan hasil belajar di kelas X MIPA 4 masih rendah.

Keterampilan proses sains yang ingin dicapai adalah melakukan percobaan sehingga diperlukan kerja sama kelompok. Oleh karena itu, model pembelajaran inkuiri terbimbing cocok untuk digunakan untuk keterampilan proses sains. Salah satu pelajaran sains adalah fisika. Cakupan materi sains atau ilmu pengetahuan alam adalah segala sesuatu mengenai alam. Sains sebagai pengetahuan yang tersusun secara sistematis. Sains juga selalu berhubungan dengan percobaan atau eksperimen. Untuk melakukan percobaan, diperlukan keterampilan yang akan membantu untuk menyelesaikan percobaan. Oleh sebab itu, keterampilan proses sains harus dilatihkan dengan pemilihan materi pembelajaran dan model pembelajaran yang tepat (Wenno, 2010).

Berdasarkan masalah di atas diperlukan model pembelajaran yang mampu meningkatkan keterampilan proses sains dan hasil belajar siswa. Model pembelajaran yang dapat digunakan adalah model inkuiri terbimbing. Menurut Daryanto (2014 :163) "Pembelajaran sains yang menekankan pada pengembangan inquiry secara rinci lebih menekankan pada aktivitas penyelidikan dan menganalisis pertanyaanpertanyaan sains". Dengan menggunakan model inkuri, pembelajaran lebih banyak menggunakan keterampilan proses yang dapat melatih siswa untuk memecahkan masalah dengan bimbingan guru dan dapat menuntut siswa untuk dapat menemukan hal baru. Pembelajaran dengan menggunakan model inkuiri terbimbing belajar tidak hanya menjadi satu arah saja, melainkan pembelajaran menjadi lebih interaktif sesuai 
yang telah diatur oleh Permendikbud Nomor 69 Tahun 2013.

Berdasarkan uraian masalah di atas, maka solusi yang dapat diterapkan untuk memperbaiki kelemahan-kelemahan tersebut adalah dengan menggunakan model pembelajaran inkuiri terbimbing. Model pembelajaran inkuiri terbimbing meningkatkan keterampilan proses sains serta tes hasil belajar siswa. Oleh karena itu, peneliti melakukan penelitian yang berjudul "Meningkatkan Keterampilan Proses Sains Menggunakan Model Inkuiri Terbimbing pada Materi Getaran Harmonis Kelas X MIPA 4 SMA Negeri 4 Banjarmasin".

\section{B. Rumusan Masalah}

Berdasarkan pada latar belakang yang telah diuaraikan di atas, dapat dirumuskan masalah secara umum, yaitu "Bagaimana cara meningkatkan keterampilan proses sains menggunakan model inkuiri terbimbing pada materi Getaran Harmonis pada kelas X MIPA 4 SMA Negeri 4 Banjarmasin?”.

Berdasarkan rumusan masalah secara umum, secara rinci rumusan masalah penelitian ini adalah sebagai berikut.

1) Bagaimana keterlaksanaan RPP fisika pada siswa kelas X MIPA 4 SMAN 4 Banjarmasin tahun pelajaran 2017/2018 melalui model pembelajaran inkuiri terbimbing pada materi getaran harmonis?

2) Bagaimana keterampilan proses sains siswa kelas $X$ MIPA 4 SMAN 4 Banjarmasin setelah guru menggunakan model pembelajaran inkuiri terbimbing pada materi getaran harmonis?

3) Bagaimana hasil belajar fisika siswa kelas $X$ MIPA 4 SMAN 4 Banjarmasin setelah guru menggunakan model pembelajaran inkuiri terbimbing pada materi getaran harmonis?

\section{Tujuan Penelitian}

Berdasarkan pertanyaan-pertanyaan pada rumusan masalah, secara umum penelitian ini bertujuan untuk mendeskripsikan cara meningkatkan keterampilan proses sains dan hasil belajar fisika siswa kelas X MIPA 4 SMA Negeri 4 Banjarmasin dengan menggunakan model pembelajaran inkuiri terbimbing pada materi gerataran harmonis.

Adapun tujuan khusus penelitian ini sebagai berikut.

1) Mendeskripsikan keterlaksanaan RPP fisika pada siswa kelas X MIPA 4 SMA Negeri 4 Banjarmasin tahun pelajaran 2017/2018 yang menggunakan model pembelajaran inkuiri terbimbing pada materi getaran harmonis.

2) Mendeskripsikan keterampilan proses sains siswa kelas X MIPA 4 SMA Negeri 4 Banjarmasin setelah guru menggunakan model pembelajaran inkuiri terbimbing pada materi getaran harmonis.

3) Mendeskripsikan hasil belajar fisika siswa kelas X MIPA 4 SMA Negeri 4 Banjarmasin setelah guru menggunakan model pembelajaran inkuiri terbimbing pada getaran harmonis.

\section{METODE PENELITIAN}

Jenis penelitian ini adalah penelitian tindakan kelas yang bertujuan meningkatkan keterampilan proses sains kelas $\mathrm{X}$ MIPA 4 SMA Negeri 4 
Banjarmasin. Penelitian Tindakan Kelas (PTK) merupakan penelitian untuk mengatasi atau memperbaiki masalah dalam proses pembelajaran. Penelitian tindakan kelas merupakan penelitian yang bertujuan untuk meningkatkan mutu dan memecahkan masalah pada subjek yang akan diteliti atau yang akan diberi tindakan (Paizaluddin \& Ermalinda, 2016). Penelitian ini dilakukan sebanyak dua siklus yang setiap siklus terdiri dari tahap perencanaan tindakan (plan), pelaksanaan (action), pengamatan (observation) dan refleksi (reflective). Penelitian tindakan kelas ini menggunakan model Stephen Kemmis dan Robbin Mc. Taggart. Berikut alur penelitian tindakan kelas ditunjukan pada gambar 1 di bawah ini.

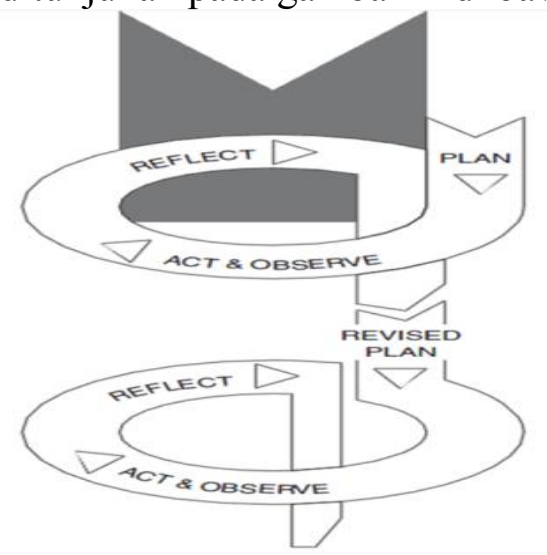

Gambar 1. Siklus Model Kemmis dan Taggart

Secara lebih rinci, tahapan kegiatan pada setiap siklus dijelaskan sebagai berikut.

\section{1) Perencanaan Awal (Plan)}

Rancangan merupakan tahap awal dalam melakukan tindakan yang harus dilakukukan peneliti sebelum melakukan tindakan. Rencana awal yang dilaksanakan meliputi:

a) Merancang dan menyusun RPP model pembelajaran inkuiri terbimbing dari 2 siklus dan dalam 1 siklus masing-masing akan dilaksanakan sebanyak 2 kali pertemuan.

b) Menyusun lembar pengamatan keterlaksanaan RPP dan keterampilan proses sains siswa.

c) Menyusun dan membuat Lembar Kegiatan Peserta Didik (LKPD), membuat materi ajar, membuat THB, serta media pembelajaran yang sesuai dengan subpokok bahasan setiap pertemuan.

\section{2) Pelaksanaan Tindakan (Action) dan Observasi (Observation)}

Setelah kegiatan menyusun rancangan tindakan selesai, selanjutnya melaksanakan tindakan atau menerapkan isi rancangan di kelas pada proses pembelajaran dengan menggunkan model inkuiri terbimbing, yang telah tersusun pada Rencana Pelaksanaan Pembelajaran (RPP). Pada saat melakukan tindakan kelas, pengamat akan melakukan pengamatan seperti keterlaksanaan Rencana Pelaksanaan Pembelajaran (RPP) dan Keterampilan Proses Sains (KPS). Pengamat yang akan mengamati keterlaksanaan Rencana Pelaksanaan Pembelajaran (RPP) adalah teman sejawat dan guru mitra, selanjutnya keterampilan proses sains akan diamati oleh 
observer. Di setiap akhir siklus siswa akan diberikan Tes Hasil Belajar (THB) untuk mengukur kognitif siswa.

\section{3) Refleksi (Reflective)}

Setelah semua data terkumpul meliputi hasil pengamatan keterampilan guru berdasarkan keterlaksanaan RPP, keterampilan proses sains, dan tes hasil belajar, selanjutnya dilakukan analisis dan refleksi antara guru/peneliti dan observer. Analisis data dilakukan melalui reduksi data, paparan, dan kesimpulan. Selanjutnya, refleksi untuk mengkaji tindakan terhadap keberhasilan pencapaian berbagai tujuan dan perlu tidaknya tindak lanjut dalam rangka mencapai tujuan akhir. Berdasarkan hasil refleksi, maka kesalahan-kesalahan yang terjadi selama pembelajaran dijadikan pertimbangan untuk memperbaiki kesalahan pada siklus berikutnya.

\section{HASIL DAN PEMBAHASAN}

\section{A. Hasil Selama Proses Pembelajaran}

Pada akhir siklus I, guru memberikan tes hasil belajar untuk mengetahui tingkat keberhasilan peserta didik dalam kegiatan pembelajaran yang telah dilakukan. Tes yang diberikan berupa tes uraian yang berjumlah 7 butir sesuai dengan tujuan pembelajaran produk. Rekapitulasi nilai dari tes hasil belajar siswa secara klasikal pada siklus I yang dapat dilihat pada tabel 1.

Tabel 1. Rekapitulasi Nilai THB Siklus I

\begin{tabular}{|c|l|c|}
\hline No & \multicolumn{1}{|c|}{ Uraian } & Hasil Siklus I \\
\hline 1 & Nilai rata-rata tes & 50,69 \\
\hline 2 & Jumlah siswa yang tuntas belajar & 6 \\
\hline 3 & Jumlah siswa seluruhnya & 28 \\
\hline 4 & Persentase yang tuntas & $21,42 \%$ \\
\hline
\end{tabular}

Tabel 1 di atas menunjukkan bahwa hasil belajar siswa yang tuntas pada siklus I hanya mencapai $21,42 \%$ atau 6 peserta didik dari 28 peserta didik. Peserta didik yang tidak tuntas mencapai $78,58 \%$ atau 22 peserta didik dari 28 peserta didik. Hasil belajar pada siklus I secara klasikal belum mencapai indikator keberhasilan, yaitu sebesar 70\%. Hal ini menunjukkan bahwa tidak semua peserta didik dapat memahami materi pembelajaran dengan baik. Hasil belajar ini perlu ditingkatkan lagi untuk perlakuan siklus II.

Pada akhir siklus II, guru memberikan tes hasil belajar untuk mengetahui tingkat keberhasilan peserta didik dalam kegiatan pembelajaran yang telah dilakukan. Tes yang diberikan berupa tes uraian yang berjumlah 6 butir sesuai dengan tujuan pembelajaran produk. Rekapitulasi nilai dari tes hasil belajar siswa pada siklus II yang dapat dilihat pada tabel 2 .

Tabel 2. Rekapitulasi Nilai THB Siklus II

\begin{tabular}{|c|l|c|}
\hline No & \multicolumn{1}{|c|}{ Uraian } & Hasil Siklus I \\
\hline 1 & Nilai rata-rata tes & 69,94 \\
\hline 2 & Jumlah siswa yang tuntas belajar & 25 \\
\hline 3 & Jumlah siswa seluruhnya & 28 \\
\hline
\end{tabular}


Upaya Meningkatkan Keterampilan Proses Sains Menggunakan Model Inkuiri Terbimbing Pada Materi Getaran Harmonis Kelas X MIPA 4

\begin{tabular}{|c|l|c|}
\hline No & Uraian & Hasil Siklus I \\
\hline 4 & Persentase yang tuntas & $89,28 \%$ \\
\hline
\end{tabular}

Tabel 2 adalah hasil belajar yang tuntas pada siklus II, yaitu mencapai 89,28 $\%$ atau 25 peserta didik dari 28 peserta didik. Peserta didik yang tidak tuntas mencapai $10,72 \%$ atau 3 dari 28 peserta didik. Hasil belajar pada siklus II secara klasikal peserta didik tuntas belajar, karena peserta didik yang memperoleh nilai $\geq 65$ adalah sebesar $89,28 \%$. Hal ini menunjukkan bahwa hasil belajar peserta didik telah memenuhi indikator keberhasilan penelitian yang diharapkan, yakni 70\%. Hal ini pula menunjukkan bahwa peserta didik telah memahami materi pembelajaran dengan baik. Berdasarkan perbandingan antara hasil belajar siswa pada siklus I dengan hasil belajar siswa pada siklus II mengalami peningkatan dari 21,42\% menjadi 89,28\%.

\section{B. Pembahasan}

Hasil belajar merupakan nilai yang diperoleh peserta didik pada setiap akhir siklus. Hasil belajar peserta didik diukur dengan menggunakan tes hasil belajar, yang akan dibandingkan dengan dengan nilai Kriteria Ketuntasan Minimum (KKM) yang berlaku di sekolahan. Nilai hasil belajar peserta didik dikatakan tuntas apabila $\geq 65$ dan tidak tuntas apabila nilai yang diperoleh $<65$. Hasil belajar setiap siklus juga dihitung secara klasikal. Ketuntasan secara klasikal juga ditentukan oleh sekolah, yaitu sebesar 70\%. Hasil evaluasi secara klasikal tes hasil belajar pada siklus I diperoleh 21,42\%, hasil belajar pada siklus II diperoleh 89,28\%.

Hasil belajar pada siklus II meningkat dan mencapai indikator keberhasilan. Hal tersebut disebabkan siswa mulai terbiasa dengan model pembelajaran yang digunakan dan peserta didik mulai dapat mengembangkan potensi yang dimiliki tanpa ada rasa canggung lagi. Hal ini sejalan dengan prinsip umum belajar menurut Sukmadinata (Suyono \& Hariyanto, 2015) prinsip umum belajar adalah bagian dari perkembangan, belajar berlangsung seumur hidup, keberhasilan belajar dipengaruhi oleh beberapa faktor diantaranya seperti lingkungan, kegiatan belajar dapat dilakukan di mana saja dan dengan siapa saja.

Tindakan yang dilakukan untuk meningkatkan hasil belajar peserta didik melalui pembelajaran dengan menerapkan model pembelajaran inkuiri terbimbing. Guru tidak mengajarkan pengetahuan secara langsung tentang konsep-konsep atau prinsipprinsip fisika tetapi peserta didik akan diarahkan untuk melakukan penyelidikan menemukan konsep atau prinsip fisika. Konsep atau prinsip tersebut diaplikasikan pada suatu permasalahan umum berupa soal tes uraian. Hal ini sesuai dengan teori belajar konstruktivisme yang menyatakan bahwa pengetahuan yang dikonstruksi oleh anak menjadi pengetahuan yang bermakna, sedangkan pengetahuan yang hanya diperoleh melalui proses pemberitahuan tidak akan menjadi pengetahuan yang bermakna. Pengetahuan tersebut hanya untuk diingat sementara setelah itu dilupakan.

Hasil belajar pada siklus I belum memenuhi indikator keberhasilan sehingga peneliti melakukan refleksi yang bertujuan untuk memperbaiki hasil belajar yang akan dilakukan pada siklus II. Berdasarkan refleksi yang dilakukan pada siklus I, guru menciptakan, menjaga, dan mengembangkan suasana belajar yang produktif serta menciptakan susana belajar yang kondusif. Hal tersebut sesuai dengan pendapat 
Piaget (Fathurrohman, 2015) berpendapat manusia secara genetik sama dan mempunyai pengalaman yang menyerupai, yang diharapkan mampu memperlihatkan kemampuan kognitif mereka. Kemampuan kognitif dikembangkan melalui lingkungan.

Berdasarkan uraian di atas, model pembelajaran inkuiri terbimbing dapat meningkatkan hasil belajar peserta didik. Hal ini sesuai dengan temuan penelitian oleh Kurniawati, Masykuri, dan Saputra (2016) dengan menggunakan model inkuiri terbimbing mampu meningkatkan keterampilan proses sains dan hasil belajar. Sebagaimana pendapat Daryanto (2014) pembelajaran dengan menggunakan model inkuiri terbimbing akan menciptkan situasi di mana siswa akan menjadi ilmuwan dan menyelesaikan masalah yang berhubungan dengan sains secara aktif dan mampu meningkatkan hasil belajar.

\section{SIMPULAN DAN SARAN}

\section{A. Simpulan}

Dengan menggunakan model inkuiri terbimbing dapat meningkatkan keterampilan proses sains dan tes hasil belajar siswa kelas X MIPA 4 SMA Negeri 4 Banjarmasin pada pokok bahasan getaran harmonis dengan cara melakukan penekanan pada beberapa hal, yaitu sebagai berikut.

(1) Pengajar menggali konseptual awal peserta didik dengan memberikan pertanyaan yang berkaitan dengan materi yang akan dipelajari, didasarkan pada demonstrasi dan motivasi yang dilakukan.

(2) Pengajar memberikan bimbingan sesuai dengan keperluan dalam hal merumuskan masalah dan hipotesis, mengidentifikasi variabel, mengumpulkan data (penyelidikan), analisis dan menyimpulkan.

(3) Pengajar memberikan penekanan pemahaman konsep yang ada pada materi ajar pada saat percobaan dan pelatihan pengerjaan soal maupun contoh soal.

(4) Pengajar memberikan dorongan dan meminta setiap kelompok untuk menyanggah maupun memberikan masukan terhadap penyelidikan kelompok.

Didukung temuan hasil penelitian pada penggunaan model pembelajaran inkuiri terbimbing di kelas X MIPA 4 SMA Negeri 4 Banjarmasin diuraikan sebagai berikut. Hasil belajar peserta didik mengalami peningkatan dari siklus I sebesar $21,42 \%$ yang tuntas menjadi $89,28 \%$ pada siklus II, sehingga dapat dinyatakan tuntas secara klasikal.

\section{B. Saran}

Beberapa saran dari hasil penelitian yang telah dilakukan sebagai berikut.

(1) Bagi peserta didik, penggunaan model pembelajaran inkuiri terbimbing dapat menumbuhkan semangat belajar peserta didik diharapkan aktif, kreatif dan inovatif dalam pembelajaran sehingga siswa yang mengalami kesulitan-kesulitan pada saat belajar dapat teratasi, dapat meningkatkan keterampilan proses sains dan hasil belajar yang lebih baik.

(2) Bagi guru, model pembelajaran inkuiri terbimbing dapat menjadi solusi menyelesaikan permasalahan keterampilan proses sains dan hasil belajar peserta 
Upaya Meningkatkan Keterampilan Proses Sains Menggunakan Model Inkuiri Terbimbing Pada Materi Getaran Harmonis Kelas X MIPA 4

didik. Guru dapat menerapkan model pembelajaran inkuiri terbimbing pada materi pokok yang berbeda sehingga model ini dapat berkembang dan bermanfaat untuk kegiatan pembelajaran.

\section{DAFTAR RUJUKAN}

Arikunto, Suharsimi. (2011). Penelitian Tindakan Kelas. Jakarta: Bumi Aksara. Ayuningtyas, Soegimin, W. \& Supardi, Z. I. (2017). Pengembangan Perangkat Pembelajaran Fisika dengan Model Inkuiri Terbimbing untuk Melatihkan Keterampilan Proses Sains Siswa SMA pada Materi Fluida Statis. JPPS: Jurnal Penelitian Pendidikan Sains, 4(2), 636-647.

Bahrudin, B., Zainuddin, Z., \& Suyidno, S. (2016). Meningkatkan Keterampilan Proses Sains Siswa Dengan Menerapkan Model Inquiry-Discovery Learning (IDL) Terbimbing. Berkala Ilmiah Pendidikan Fisika, 1(3), 245-258.

Daryanto. (2014). Pembelajaran Tematik, Terpadu, Terintegrasi Kurikulum 2013. Yogyakarta : Gava Media.

Indonesia, P. R. (2015). Peraturan Pemerintah Republik Indonesia Nomor 13 Tahun 2015 tentang Perubahan kedua atas Peraturan Pemerintah Nomor 19 Tahun 2005 tentang Standar Nasional Pendidikan. Jakarta: Kementrian Sekretariat Negara RI.

Kusnandar. (2013). Langkah Mudah Penelitian Tindakan Kelas sebagai Pengembangan Profesi Guru. Jakarta: PT. Raja Grafindo Persada.

Muspawi, Mohamad. (2014). Profesionalitas Guru dalam Menyusun Rencana Pelaksanaan Pembelajaran (RPP) pada Sekolah Dasar Negeri No 76/IX Desa Mendalo Darat Kecamatan Jaluko Kabupaten Muaro Jambi. Jurnal Pendidikan Universitas Jambi Seri Humaniora, (17) 1, 57-62.

Paizaluddin \& Ermalinda. (2016). Penelitian Tindakan Kelas. Bandung : Alfabeta.

Shoimin Aris. (2014). 68 Model Inovatif dalam Kurikulum 2013. Yogyakarta: Ar Ruzz Media,

Sudjana, Nana. (2017). Penilaian Hasil Proses Belajar Mengajar. Bandung: PT Remaja Rosdakarya.

Zainil, Arifin. (2012). Evaluasi Pembelajaran. Jakarta: Direktorat Jenderal Pendidikan Islam Kementerian Agama RI. 